\title{
INA-Rxiv: The Missing Puzzle in Indonesia's Scientific Publishing Workflow
}

\begin{abstract}
R Rahim 1 , M Zarlis ${ }^{2}$, D E Irawan ${ }^{3}$, N Kurniasih ${ }^{4}$, H Djanggih ${ }^{5}$, S Sallu ${ }^{6}$, D E Indriani ${ }^{7}$, A S Ahmar $^{8}$, Y Yetti', A Hasibuan ${ }^{10}$, A Aswari ${ }^{11}$, D Hartama ${ }^{12}$, R Ratnadewi ${ }^{13}$, D Napitupulu ${ }^{14}$, M

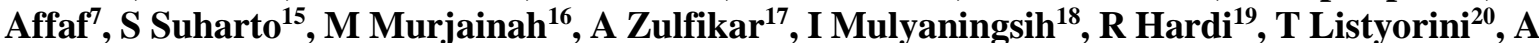
P Pradana ${ }^{21}$, A Ariyanto ${ }^{9}$, N Qamar ${ }^{22}$, R Hidayat ${ }^{23}$, S Sriadhi ${ }^{24}$, D Siregar ${ }^{25}$, M I Setiawan ${ }^{26}$, J Simarmata $^{27}$, T M Diansyah ${ }^{28}$, D U Sutiksno ${ }^{29}$, M A Prasnowo ${ }^{30}$, R F Nanuru ${ }^{31}$, A A Gde Satia Utama $^{32}$, A Hendrawan ${ }^{15}$, Achmad Daeng GS ${ }^{33}$, L D Putri', A Najmurrokhman ${ }^{34}$, F Soehardi', D Abdullah ${ }^{35}$, M Ratodi ${ }^{34}$, L Arliman $\mathrm{S}^{35}$, E $\mathbf{R}$ Gultom $^{36}$, G Ginting ${ }^{37}$, R N Yanti ${ }^{9}$, A Iskandar ${ }^{38}$, I Coryanata ${ }^{39}$, I K Siregar ${ }^{40}$, S S Wahyuni ${ }^{41}$, A Ardiansah', V Amelia ${ }^{9}$, M Mahjudin ${ }^{33}$, H Fajrin $\mathbf{R}^{42}$, E Emrizal $^{43}$, S Susiana ${ }^{44}$, D H Saputra ${ }^{45}$, N Setyowati ${ }^{41}$, D Nofriansyah ${ }^{46}$, T Suryanto ${ }^{47}, K$ Saddhono $^{48}$, C A Sugianto ${ }^{49}$, H Ahmad $^{50}$, L Abdillah ${ }^{51}$, R Rochmady ${ }^{52}$, AAAP Ardyanti ${ }^{53}$, MBN Wajdi $^{54}$, A P U Siahaan', M Mesran ${ }^{37}$, I Saputra ${ }^{37}$, F T Waruwu ${ }^{37}$, S Suginam ${ }^{37}$, E Buulolo ${ }^{37}$ and J Abraham ${ }^{56}$
\end{abstract}

${ }^{1}$ Universiti Malaysia Perlis, ${ }^{2}$ Universitas Sumatera Utara, ${ }^{3}$ Institut Teknologi Bandung, ${ }^{4}$ Universitas Padjadjaran, ${ }^{5}$ Universitas Tompitika Luwuk Banggai, ${ }^{6}$ Universitas SembilanBelas November Kolaka Sulawesi Tenggara, ${ }^{7}$ STKIP PGRI Bangkalan, ${ }^{8}$ Universitas Negeri Makassar, ${ }^{9}$ Universitas Lancang Kuning, ${ }^{10}$ Universitas Islam Sumatera Utara, ${ }^{11}$ Universitas Muslim Indonesia, ${ }^{12}$ Sekolah Tinggi Ilmu Komputer Tunas Bangsa, ${ }^{13}$ Universitas Kristen Maranatha, ${ }^{14}$ Indonesian Institute of Sciences, ${ }^{15}$ Universitas Negeri Semarang, ${ }^{16}$ Universitas PGRI Palembang, ${ }^{17}$ Universitas Hasanuddin, ${ }^{18}$ IAIN Syekh Nurjati Cirebon, ${ }^{19}$ STMIK Balikpapan, ${ }^{20}$ Universitas Muria Kudus, ${ }^{21}$ Universitas Borneo Tarakan, ${ }^{22}$ Universitas Muslim Indonesia, ${ }^{23}$ Politeknik Negeri Padang, ${ }^{24}$ Universitas Negeri Medan, ${ }^{25}$ Universitas Harapan Medan, ${ }^{26}$ Narotama University, ${ }^{27}$ Politeknik Negeri Ambon, ${ }^{28}$ Universitas Maarif Hasyim Latif, ${ }^{29}$ Universitas Halmahera, ${ }^{30}$ Universitas Airlangga, ${ }^{31}$ Universitas 45 Surabaya, ${ }^{32}$ Universitas Jenderal Achmad Yani, ${ }^{33}$ Universitas Malikussaleh, ${ }^{34}$ Universitas Islam Negeri Sunan Ampel, ${ }^{35}$ Sekolah Tinggi Ilmu Hukum Padang, ${ }^{36}$ Universitas Trisakti, ${ }^{37}$ STMIK Budi Darma, ${ }^{38}$ STMIK AKBA, ${ }^{39}$ Universitas Bengkulu, ${ }^{40}$ Universitas Muhammadiyah Sumatera Utara, ${ }^{41}$ Universitas Brawijaya, ${ }^{42}$ Balai Bahasa Sulawesi Selatan, ${ }^{43}$ STIFAR Pekanbaru, ${ }^{44}$ Universitas Maritim Raja Ali Haji, ${ }^{45}$ Universitas Nahdlatul Wathan Mataram, ${ }^{46}$ Sekolah Tinggi Manajemen dan Informatika Komputer Triguna Dharma, ${ }^{47}$ Universitas Islam Negeri Raden Intan Lampung, ${ }^{48}$ Universitas Sebelas Maret Surakarta, ${ }^{49}$ Politeknik TEDC Bandung, ${ }^{50}$ Universitas Al Asyariah Mandar, ${ }^{51}$ Universitas Bina Darma, ${ }^{52}$ Sekolah Tinggi Ilmu Pertanian Wuna Raha, ${ }^{53}$ STMIK Primakara, ${ }^{54}$ STAI Miftahul Ula Nganjuk, ${ }^{56}$ Bina Nusantara University

*usurobbi85@zoho.com

Abstract. INA-Rxiv is the first Indonesia preprint server marking the new development initiated by the open science community. This study aimed at describing the development of INA-Rxiv and its conversations. It used analyzer of Inarxiv.id, WhatsApp Group Analyzer, and Twitter Analytics as the tools for data analysis complemented with observation. The results showed that INA-Rxiv users are growing because of the numerous discussions in social media, e.g. WhatsApp, as well as some other positive response of writers who have been using INA-Rxiv. The perspective of growth mindset and the implication of INA-Rxiv movement for filling up the gap in accelerating scientific dissemination process are presented at the end of this article. 


\section{INTRODUCTION}

Dissemination of research [1], like via INA-Rxiv Preprint Server Indonesia [2], is strategic for speeding up research claims that can be acknowledged and used by other researchers. INA-Rxiv is not the only preprint server available. sThe paper licenses uploaded to INA-Rxiv are CC-BY (Creative Common Attribution) to guarantee the freedom of usage as long as the source acknowledged. Providing preprint or author original version (AOV) on a community-based preprint server endorses Open Access practice, which means free to re-use, free to remix, and free to redistribute.

INA-Rxiv was soft launched on August 17, 2017. It has proven to be in the major league, by hosting 1000+ papers in just three months (August-November 2017). From the initiation of INA-Rxiv by Open Science activists until INA-Rxiv is becoming known today, social media was very helpful. INA-Rxiv is growing with many posts on various social media such as Facebook (Openscience Inarxiv), Twitter (@inarxiv_id), Telegram (e.g. IDRI) and also WhatsApp. WhatsApp was the most widely used social media [3] among lecturers or researchers.

INA-Rxiv carrying the concept of Open Access [4] [5] indexed in Google Scholar [6] could be a solution to improve publications and citations both for personal and institutional. The Open Science Framework (OSF), a not-for-profit institution, as the backbone of INA-Rxiv, provides a nearly unlimited cloud storage space, where Indonesian and Indonesianist authors can store their papers along with supplementary files and datasets (data, image, and codes). Now it is easy for academics to upload (1) preprint articles (prior peer review), without having to wait for the long winding road of the review process, (2) postprint articles, and even (3) articles that have been published but hasn't online.

Matthias and Tennant [7] explained the preprint and postprint process schemes as shown in Figure 1. Nowadays, the most authors know solely the publication version issued by the journal publishers. Preprint and postprint publications [8] [9] [10] are article versions that have not been widely used to accelerate the results of research dissemination. In the process of publishing the article, there are several stages to be completed, e.g. a review process that takes 3 months or even 1 year. Meanwhile, an article which under review process would be useful for other researchers if there is a preprint version that can be used [8]. Another case is a paper published in the Non-Open Access journal requires a paid subscription to the publisher for the article to be read or downloaded. It would be more accessible if there is a postprint version of the article, all free for readers.

This study aimed at presenting the development of INA-Rxiv and the use of social media as a forum for the socialization of INA-Rxiv.

\section{METHODS}

This study used descriptive design to analyze the sum and distribution of discussions about INARxiv and open science in general sense. Data were taken and analyzed with https://inarxiv.id frequency analyzer, WhatsApp Analyzer of INA-Rxiv Group from middle August 2017 to early October 2017 as well as Twitter Analytics. 


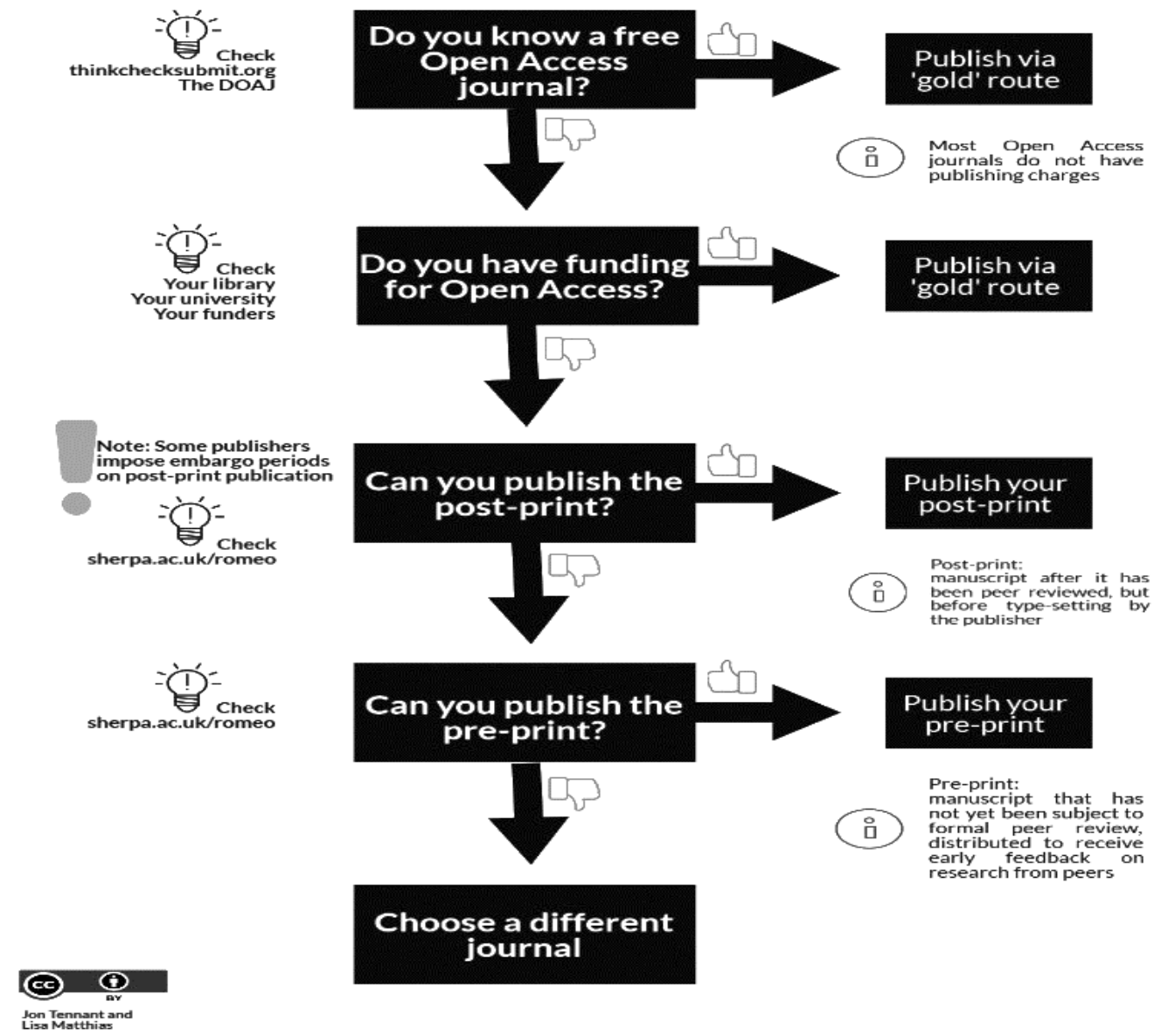

Figure 1. Preprint and Postprint Open Access Scheme: How to Make Your Research Open Access for Free and Legally

\section{RESULTS AND DISCUSSION}

One week since its soft launching (August 17, 2017) [11], INA-Rxiv received 77 articles. The majority of the articles came from Physical Sciences and Math (35 articles), Engineering (12 articles), Social and Behavioral Sciences ( 8 articles), Education Science ( 8 articles), Medicine and Health Sciences ( 8 articles). The rest came from Business, Law, as well as Life Science.

On October 14, 2017, the increase of articles on INA-Rxiv has reached a total of 638 Articles (more than $800 \%$ increasing). It might be caused by massive socialization of questions and testimonials from curious lecturers or researchers about INA-RXIV and its benefits. The majority of the articles came from Physical Science and Math (180 articles), Engineering (160 articles), Education Science (60 articles), Life Sciences (55 articles), Arts and Humanities (55 articles) as well as Social and Behavior Sciences (40 articles). The rest came from Law as well as Medicine and Health Sciences.

Figure 2 shows that the chat activity on the group was quite active at $6 \mathrm{pm}$ to $9 \mathrm{pm}$, which is nonworking hours. The discussions were about technical bits on INA-Rxiv concepts and uploading techniques, Scopus indexing and how to get published in journals and proceedings. There were also several feedbacks for the national-wide promotion system and positive feedback on how to make the most from INA-Rxiv in research workflow. 


\section{Number of messages by hour of day}

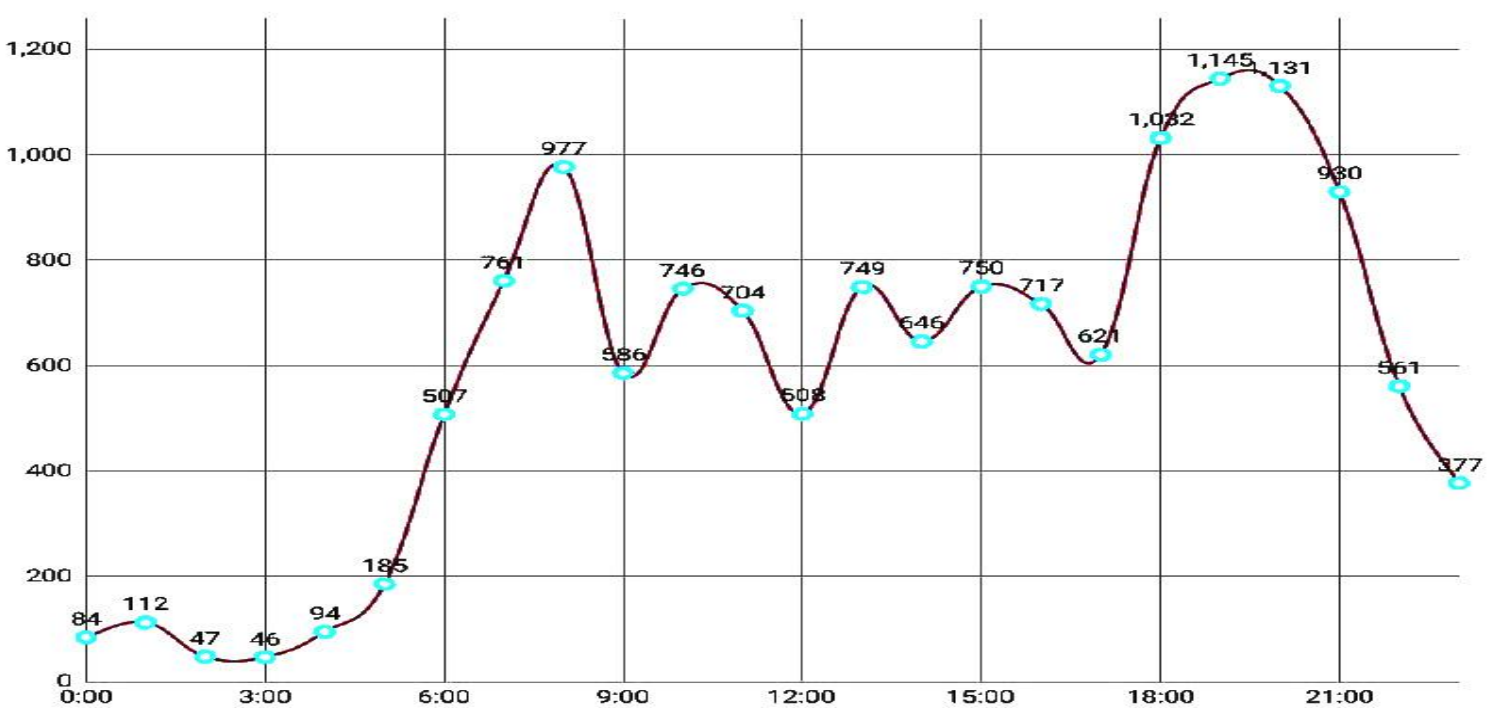

Figure 2. Chat Messages about Publication and INA-Rxiv

Twitter analytics shows an overwhelming sum of impressions or engagements gained from tweets which generated from INA-Rxiv twitter handle (@inarxiv_id). Since August 6, 2017, a week before Open Science Framework (OSF) officially launched INA-Rxiv and the other five preprint servers, to October 31, 2017, the Twitter handle had earned 120,000 impressions. This was considered as a huge start.

Based on the observation on the dialogues that occurred through the WhatsApp group, only a few questioned the mechanism of deletion of files that have been uploaded to INA-Rxiv. Questions about file removal are generally triggered by two subjective things. First, the writers' worry that the editorial board member of future journal publication target will accuse him/her of self-plagiarism, as evidenced by the similarity level of content between the submitted article and the one saved and announced in INA-Rxiv. Secondly, the writers" evaluation that the uploaded article is a "rushed" or "error" version containing either substantive, fundamental, and/or redactional error.

The first concern has been eroded with objective fact that "major" publishers can justify the dissemination of manuscripts through preprint servers. SAGE Publishing, for example, clearly states that "Prior publication of datasets or deposition in a preprinted server do not constitute prior publication" [12]. Manuscripts posted in the preprint server are not classified as a "publication", so allegations of self-plagiarism or double publication that are unethical can not be addressed to the author [13]. The second concern related to the psychological aspects of a person, i.e. the mindset.

Dweck [14] divided the mindset into two, namely fixed mindset and growth mindset. The characteristics of a person with a fixed mindset are (1) assumes that his/her intelligence, character, and personality are permanent entities at all times, (2) wants to constantly indicate or show off their talents, skills, expertise, personality, and character; (3) can not tolerate errors or setbacks, even tend to be depressive because of them, (4) his/her self-confidence is more vulnerable due to errors because the mistake done---though occurring only once---is considered a part of his/her deep personal identity, (5) seeks to nurture and protect his/her self-esteem by proving his/her performances and collecting a lot of recognition and confirmation; if there is a failure they will seek "scapegoat", do "revenge" when there is a way or opportunity (just to feel win and superior above others), or resist to try further. The characteristics of people with growth mindset are (1) see their intelligence and personality as entities that can change and evolve over time, (2) give meaning to their mistakes or failures as a means for learning, (3) appreciate processes, not results, and are more able to consider the situational aspects in 
their attributions, (4) their confidence is not threatened by failure, and (5) find pleasure in challenges and is not busy attaining and proving perfection.

The growing number of articles in INA-Rxiv coupled with very few complaints regarding the INA-Rxiv policy---stating that "When you add a new version of a file with the same name to your OSF project, the OSF automatically updates the file and maintains a record of all previous versions stored on OSF Storage" [15] (see also its predecessor policy, arXiv, which states "arXiv makes all previous versions of submissions publicly available (since October 1997). Therefore, even though the current version of a paper may be marked as withdrawn, previous versions can still be retrieved" [16])---can also be viewed from the perspective of the mindset.

Based on the reality, it appears that most academics in Indonesia who uploads their manuscript to INA-Rxiv have growth mindset in the academic field. The academics feel fine that the history or evolutive traces of their manuscripts (version 1, version 2, version 3, and so on) in INA-Rxiv storage can still be accessed and traced transparently. This shows that they dare to face themselves in the midst of public presence. The public is not positioned as the party that will sentence their ability level. In other words, they enjoy the process of perfecting their articles from the obtained feedbacks, not expecting recognition of perfection about how great their articles are. By storing and disseminating manuscripts via INA-Rxiv they are actually very enthusiastic to learn and gain more criticism for their development. Although the Google Scholar indexation of manuscripts stored in INA-Rxiv is a tantalizing potential, the motive of Indonesian academics joined in INA-Rxiv is clear enough, i.e. involving themselves in a "knowledge crises." Knowledge is always seen in a series of "crisis after crisis" that will drive the advance of that knowledge. The crises coped with ambiguity tolerance [17] are viewed as a site for sharing, correcting self, and sustaining happiness (not pressure and suffering) in the dynamics of knowledge production. The facilitation of INA-Rxiv reduces social loafing [18] in the academic virtual team and it creates optimism for the gait of Indonesian academics.

The dynamics, as indicated by the data, are experiencing proliferation because of appropriation of INA-Rxiv---in addition to the growth mindset (self/personal aspect) and socialization (social aspect). Appropriation [19] refers to a dynamic activity of which INA-Rxiv does not merely serve as firstly initiated, i.e. as a preprint server for knowledge dissemination and feedback acquisition from a variety of openly and ubiquitously distributed resources (e.g. "peer-as-reviewer" vis-à-vis "expert peer reviewer") in one's virtual and social environments; but also, to mark the journey of effort in reaching novelty or originality in a research, and, more essentially, celebrates human freedom. We can view the appropriation in the condition that when our idea or even worse, our documents, have been stolen. How do we prove that we are the first to make an idea or draft the document? That's what INA-Rxiv is for. We can say, "INA-Rxiv---Feel the freedom."

\section{CONCLUSION}

INA-Rxiv can be a solution for the dissemination process because it receives preprint and postprint versions of a manuscript (author version) that can be widely disseminated; both preserve author's original copyright. It is also the missing puzzle in scientific workflow since it allows an immediate public claim of a work and public feedback as well. WhatsApp as a social media has been successfully used to spread the messages on INA-Rxiv, preprint, and postprint to lecturers and researchers.

Further development of this paper may address the effects of INA-Rxiv to improve institutional publications and the number of articles and citations in Indonesia's SINTA (Science and Technology Index; sinta.ristekdikti.go.id) record, and how the Indonesian Ministry of Research, Technology, and Higher Education could use it to improve the quantity and quality of publication in Indonesia.

\section{REFERENCES}

[1] D. E. Irawan, C. N. Rachmi, H. Irawan, J. Abraham, K. Kusno, M. T. Multazam, K. K. Rosada, S. H. Nugroho, G. Kusumah, D. Holidin and N. A. Aziz, "Penerapan Open Science di Indonesia Agar Riset Lebih 
Terbuka, Mudah Diakses, dan Meningkatkan Dampak Saintifik," Berkala Ilmu Perpustakaan dan Informasi, vol. 13, no. 1, pp. 25-36, 2017.

[2] D. E. Irawan, "INA-Rxiv: The Indonesia preprint server," Medium Corporation, [Online]. Available: https://medium.com/open-science-indonesia/ina-rxiv-2a51aae69d3a.

[3] T. Sutikno, L. Handayani, D. Stiawan, M. A. Riyadi and I. M. I. Subroto, "WhatsApp, Viber and Telegram: which is the Best for Instant Messaging?," International Journal of Electrical and Computer Engineering (IJECE), vol. 6, no. 3, pp. 909-914, 2016.

[4] E. C. McKiernan, P. E. Bourne, C. T. Brown, S. Buck, A. Kenall, J. Lin, D. Dougall, B. A. Nosek, K. Ram, C. K. Soderberg, J. K. Spies, K. Thaney, A. Updegrove, K. H. Woo and T. Yarkoni, "Point of View: How open science helps researchers succeed," eLife, p. 5, 2016.

[5] V. Tracz and R. Lawrence, "Towards an open science publishing platform [version 1; referees: 2 approved]," F1000Research, vol. 5, 2016.

[6] L. Dixon, C. Duncan, J. C. Fagan, M. Mandernach and S. E. Warlick, "Finding articles and journals via Google Scholar, journal portals, and link resolvers: Usability study results," Reference \& User Services Quarterly, vol. 50, no. 2, pp. 170-181, 2010.

[7] L. Matthias and J. Tennant, "How to make your research open access? For free and legally," Figshare, 2017. [Online].

Available: https://figshare.com/articles/How_to_make_your_research_open_access_For_free_and_legally_/5285512.

[8] H. W. Inefuku, "Pre-Print, Post-Print or Offprint? A guide to publication versions, permissions and the digital repository," Digital Repository @ Iowa State University, 2013. [Online]. Available: http://lib.dr.iastate.edu/digirep_outreach/2.

[9] B. Swoger, "Understanding your rights: pre-prints, post-prints and publisher versions," Scientific American, [Online]. Available: https://blogs.scientificamerican.com/information-culture/understanding-your-rightspre-prints-post-prints-and-publisher-versions/.

[10] E. Amsen, "Guide to open science publishing," F1000Research, 2015:21.

[11] D. E. Irawan, "INArxiv: 7 days and 77 preprints," [Online]. Available: dasaptaerwin.net/wp/2017/08/inarxiv-enthusiasts.html.

[12] A. Anonym, "Frequently Asked Questions," Sage Publishing, [Online]. Available: https://insights.sagepub.com/author_resources.php?folder_id=120.

[13] C. L. Curry, "SHERPA Services and SHERPA/RoMEO," Journal of Electronic Resources in Medical Libraries , pp. 1-4, 2017.

[14] C. S. Dweck, Mindset: The New Psychology of Success, Ballantine Books, 2007.

[15] A. Anonym, "File Revisions and Version Control," Open Science Framework, [Online]. Available: http://help.osf.io/m/files/1/524182-file-revisions-and-version-control.

[16] a. administrators, "To withdraw an article," Cornell University, [Online]. Available: https://arxiv.org/help/withdraw.

[17] J. Abraham and A. Falah, "Is Virtual Marriage Acceptable? a Psychological Study Investigating the Role of Ambiguity Tolerance and Intimacy Illusion in Online Dating among Adolescents and Early Adults," Journal of Psychological and Educational Research, vol. 24, no. 2, pp. 117-143, 2016.

[18] J. Abraham and M. Trimutiasari, "Sociopsychotechnological Predictors of Individual's Social Loafing in Virtual Team," International Journal of Electrical and Computer Engineering (IJECE), vol. 5, no. 6, pp. 1500-1510, 2015.

[19] T. Prayoga and J. Abraham, "A psychological model explaining why we love or hate statistics," Kasetsart Journal of Social Sciences, vol. 38, no. 1, pp. 1-8, 2017. 